\title{
The therapeutic benefits of natural cannabinoids in delaying the pathophysiology of
}

\section{Alzheimer's disease}

Os benefícios terapêuticos dos canabinoides naturais no retardo da fisiopatologia da Doença de Alzhemer

Los beneficios terapéuticos de los cannabinoides naturales para retrasar la fisiopatología de la enfermedad de Alzheimer

Received: 04/24/2021 | Reviewed: 05/01/2021 | Accept: 05/04/2021 | Published: 05/18/2021

\author{
Daniel Alexandre Lima Cavalcante \\ ORCID: https://orcid.org/0000-0001-9257-0569 \\ Centro Universitário Internacional, Brazil \\ E-mail: ten2487@yahoo.com.br \\ Laura Trindade Fernandes \\ ORCID: https://orcid.org/0000-0002-1671-576X \\ Centro Universitário do Vale do Iguaçu, Brazil \\ E-mail: Laura_fisio94@hotmail.com
}

\begin{abstract}
Objectives: To analyze and evaluate the current conjuncture inherent to the therapeutic use of natural cannabinoids in delay and protection against the pathophysiological actions caused by Alzheimer's disease. Methods: Overview of systematic reviews. The search and selection of the studies were predominantly in the databases of the Medical Literature Analysis and Retrieval System Online (Medline), National Library of Medicine (Pubmed) and Scientific Electronic Library Online (SciELO) in the period between March and August 2020. Key findings: Current results showed promising therapeutic effects of natural cannabinoids in the treatment of Alzheimer's disease, such as reduction of motor and cognitive symptoms, and protective neuroprotective action. These results can be explained, in part, by the anti-inflammatory, antioxidant, antagonist action of CB1 receptors, as well as by the activation of PPARgamma receptors produced by these substances. Conclusions: The systematic research presented in this overview converges in the sense that the therapeutic applications provided by natural cannabinoids and their analogues may play a unique role in the modulation of molecular targets involved in central nervous system dysfunctions caused by Alzheimer's disease, thus enabling the development of innovative drugs, safer and more effective in the treatment of patients not responsive to conventional clinical practice, with significant improvement in quality of life.
\end{abstract}

Keywords: Alzheimer's disease; Pathophysiology; Neurology; Natural cannabidiodes.

\begin{abstract}
Resumo
Objetivo: Analisar e avaliar a atual conjuntura inerente à utilização terapêutica dos canabinoides naturais no retardo e proteção contra as ações fisiopatológicas ocasionadas pela doença de Alzhemer, destacando alguns dos principais mecanismos bioquímicos e moleculares subjacentes à referida proteção, bem como, quais as perspectivas de utilização de tais agentes a curto e médio prazo, na busca por um tratamento mais eficiente contra tal patologia. Métodos: Overview de revisões sistemáticas. A busca e a seleção dos estudos transcorreram predominantemente nas bases de dados da Medical Literature Analysis and Retrieval System Online (Medline), National Library of Medicine (Pubmed) e Scientific Electronic Library Online (SciELO), no período compreendido entre março e agosto de 2020. Foram combinando os termos Doença de Alzhemer, fisiopatologia, farmacologia e canabidiodes naturais. Como fator prioritário dos critérios de inclusão, foram selecionados revisões sistemáticas com ou sem metanálise, publicadas nos últimos 5 anos, que discorressem detalhadamente sobre o tema. Após a aplicação dos critérios de inclusão e exclusão, foi realizada a análise das pesquisas as quais se alinhavam ao objetivo da coleta. Resultados: Os resultados atuais mostraram efeitos terapêuticos promissores do canabinoides naturais no tratamento da doença de Alzhmer, tais como redução de sintomas motores e cognitivos, e ação neuroprotetora. Tais resultados podem ser explicados, em parte, pela ação antiinflamatória, antioxidante, antagonista de receptores CB1, bem como, pela ativação dos receptores PPAR-gama produzido por estas substâncias. Conclusões: As pesquisas sistemáticas apresentadas nesse overview convergem no sentido de que a aplicações terapêuticas proporcionadas pelos canabidiodes naturais e seus análogos podem desempenhar papel singular na modulação de alvos moleculares envolvidos em disfunções do sistema nervoso central, ocasionadas pela doença de Alzhemer, possibilitando assim o desenvolvimento de fármacos inovadores, mais
\end{abstract}


seguros e eficazes no tratamento de pacientes não responsivos à clínica convencional, com melhora significativa na qualidade de vida.

Palavras-chave: Doença de Alzheimer; Fisiopatologia; Neurologia; Canabidioides naturais.

\section{Resumen}

Objetivo: Analizar y evaluar la situación actual inherente al uso terapéutico de dos cannabinoides naturales que no retrasan y protegen frente a las acciones fisiopatológicas provocadas por la enseñanza de Alzhemer, destacando algunos de los dos principales mecanismos bioquímicos y moleculares subyacentes a esta protección, así como, Cuáles son las perspectivas de uso Estos agentes son de corto y mediano plazo, buscando un tratamiento más efectivo frente a dicha patología. Métodos: Resumen de revisiones sistemáticas. La búsqueda de una selección de dos estudios atravesará predominantemente las bases de datos Medical Literature Analysis and Retrieval System Online (Medline), National Library of Medicine (Pubmed) y Scientific Electronic Library Online (SciELO), sin período entre marzo y agosto de 2020. The Alzhemer's Se combinaron termo de enfermedades, fisiopatología, farmacología y cannabidiodes naturales. Como factor de prioridad para dos criterios de inclusión, seleccionamos revisiones sistemáticas en forma de semi-metaanálisis, publicadas en los últimos 5 años, que difieren en los detalles sobre el tema. Además de la aplicación de dos criterios de inclusión y exclusión, se realizó un análisis de las investigaciones en cuanto a alineación con el objetivo de la cola. Resultados: Los resultados actuales mostrarán efectos terapéuticos prometedores de los cannabinoides naturales no con el tratamiento de la enfermedad de Alzheimer, como la reducción de los síntomas motores y cognitivos y la acción neuroprotectora. Estos resultados pueden explicarse, en parte, por el antiinflamatorio, antioxidante, antagonista de los receptores CB1, así como por la activación de dos receptores PPAR-gamma producidos por estas sustancias. Conclusiones: Las investigaciones sistemáticas presentadas en un resumen convergen sin la noción de que las aplicaciones terapéuticas proporcionadas por las hebras de cannabidos naturales y sus análogos pueden jugar un papel único en la modulación de dianas moleculares involucradas en disfunciones del sistema nervioso central, causadas por la posibilidad de desarrollo. , asumiendo fármacos innovadores, más seguros y más efectivos, sin tratar a pacientes que no responden a la práctica convencional, con un tiempo significativo en la calidad de vida.

Resumen: Enfermedad de Alzheimer; Fisiopatología; Neurología; Cannabidiodes naturales.

\section{Introduction}

Alzheimer's disease was first diagnosed in mid-1907 by german neurologist Alois Alzheimer, when the case of a patient who was losing his mental faculties over four years was recorded, as well as, were first evidenced, in post mortem analysis some severe anomalies known as neuro fibrillary plaques within amyloids and neurons (Bondi et al., 2017)

Since the aforementioned date, there has been a rapid proliferation of studies and research on Alzheimer's disease (AD). Studies conducted in 1978 show that $10 \%$ of people over 65 years of age suffer organic lesions due to senility, of which $75 \%$ are highly likely to develop $\mathrm{AD}$, while the remaining $25 \%$ correlate with certain amendments produced by multiple infarctions (Bondi et al., 2017; Robinson et al., 2017).

Alzheimer's pathology is characterized as a neurodegenerative disease. Its progression is characterized by the appearance of disabling neuropsychiatric and cognitive-behavioral symptoms, significantly impacting the life of the patient and his caregiver (Fan et al., 2020). Among the symptoms, memory loss, depression, psychomotor agitation, affective disorders with social isolation, inability to face recognition, among others stand out (Agüera \& López, 2017). It is one of the most prevalent causes of dementia. Epidemiology shows a constant increase in the number of cases, making such a pathology an economic and social problem of global proportions (Dong et al., 2017).

Post-mortem anatomopathological analyses of the temporal cortex of patients committed by Alzheimer's disease showed extracellular accumulations of beta-amyloid proteins, the said proteins can generate neural plaques. In the intracellular environment, neurofibril tangles consisting of hyperphosphorylade tau proteins were observed. Such a protein in its normal physiology ensures the proper architecture of the cytoskeleton of neural cells. These findings, in accordance with the neuroinflammatory process and increased oxidative stress present in neural tissues, are directly related to the development and progression of AD (Kantarci et al., 2020; De Falco et al., 2016). Neuroinflammation is interconnected with the activation of microglia, which phagocytes beta-amyloid deposits generating cytokines with pro-inflammatory characteristics (TNF-alpha, 
chemokines and IL-1). In continuity the pathophysiological actions of the disease, there is also the release of glutamate and reactive variations of oxygen, causing neurotoxicity and oxidative damage, generating a significant increase in brain damage (Xie et al., 2020; Mc Donough, 2017). Another factor responsible for the beginning of the pathophysiological cycle is the reduction of cholesterol synthesis, a process linked to neurodegeneration and etiology of AD (Oliveira et al., 2018).

In the current situation, the drug therapies used in the treatment of Alzheimer's disease present questionable results, considering that they act mainly in the relief of symptoms, with little influence on the current course of the disease. The current drug level offers only benefits restricted to the preservation of cognitive function. In addition, a wide range of adverse effects is well documented in the literature (Watt \& Karl, 2017). Some behavioral symptoms characteristic of AD can be minimized with the use of other medications of various classes, such as antidepressants, antipsychotics, anticonvulsants, and benzodiazepines, however this practice significantly increases the probability of adverse reactions and drug interactions (Blesa et al., 2018; Hane et al., 2017).

The therapeutic limitations that we find today to minimize symptoms and slow the progression of AD, highlights the need for research and development of new treatment options for Alzheimer's. Cannabinoid derivatives, can be seen as new therapeutic potentials for the treatment of Alzheimer's disease, thus, the development of new research involving natural cannabinoids, with better control between therapeutic and side effects, has been presented as an important and innovative alternative for this therapy.

Seeking to evaluate possible solutions to this problem, this research aimed to analyse in detail the protective effects caused by natural cannabinoids in the treatment of Alzheimer's disease. Compiling the most up-to-date information and highlighting the main biochemical and molecular mechanisms responsible for this protection.

\section{Methodology}

This research is a literature review, about the benefits provided by the use of natural cannabinoids in the delay and protection of pathophysiological actions caused by Alzheimer's disease, highlighting the main biochemical and molecular mechanisms related to such protection, as well as, what are the prospects of using such agents in the short and medium term, in the search for a more efficient treatment. The bibliographic survey was carried out electronically during the period from March to August 2020. The following inclusion criteria were established: electronically available scientific studies in the databases of the Medical Literature Analysis and Retrieval System Online (Medline) and Scientific Electronic Library Online (SciELO), as well as included studies published in other international journals of notable interest in the Scientific Electronic Library Online (area, with innovative discoveries inherent to the scope of the theme). As a priority factor of the inclusion criteria, articles published in the last 5 years that discuss the subject in detail, or that, at any date, present some relevant statistical or historical information related to the subject of this research were selected. Publications with a different approach to the proposed theme (endocannabinoids and synthetic cannabinoids) were excluded.

The key words were used: Alzheimer's disease, senile dementia, pathophysiology, disease progression, pharmacology, natural cannabinoids and CBD. After applying the inclusion criteria, the titles and abstracts of the articles were evaluated and those that were in line with the objective of the collection were selected (Figure 1). 
Figure 1. PRISMA flowchart of literature search. [Colour figure can be viewed at wileyonlinelibrary.com].
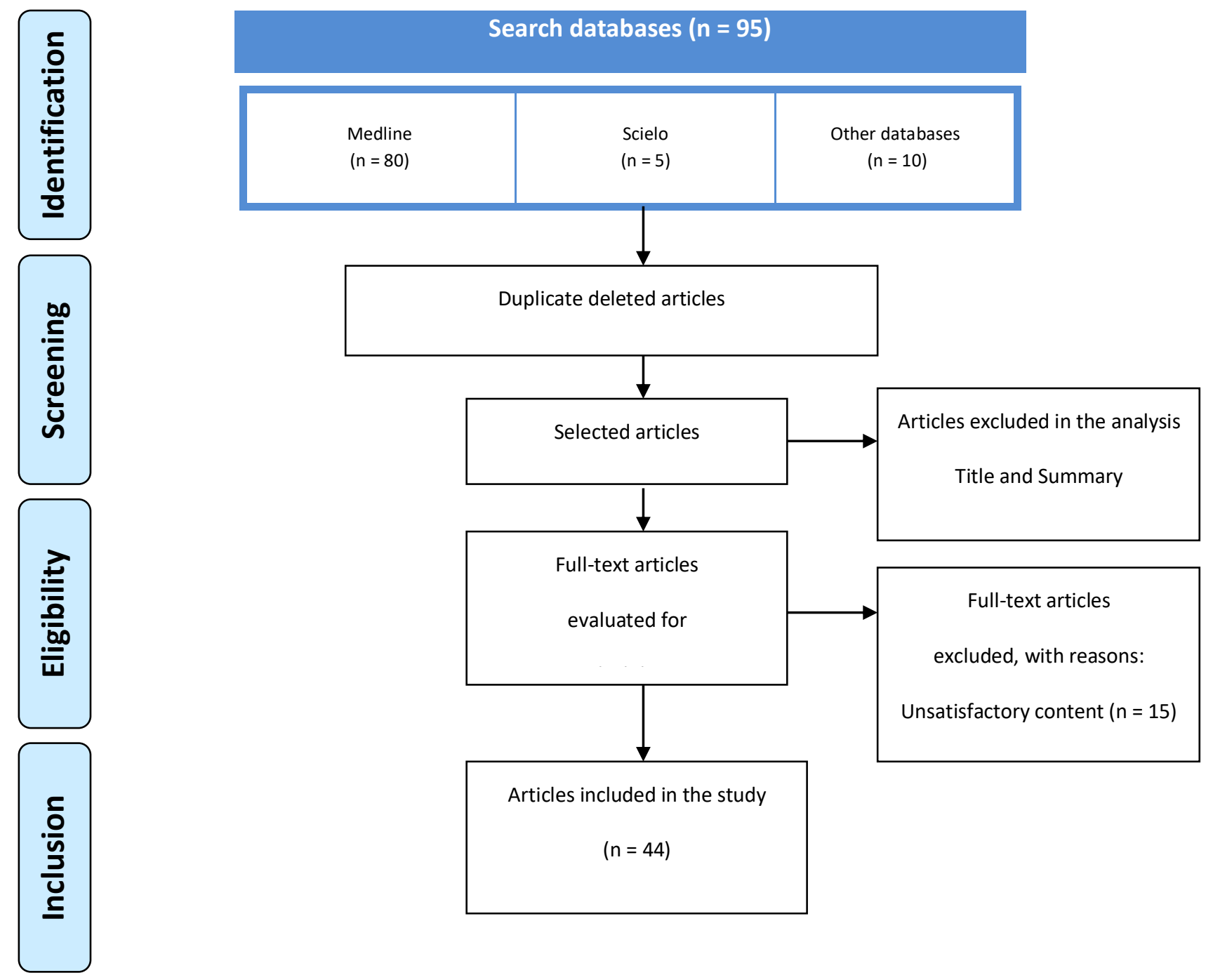

Source: Authors.

\section{Results and Discussion}

\section{The epidemiology and pathophysiology of Alzheimer's disease}

Alzheimer's disease is an important public health problem of epidemic proportions and is part of the context of the accelerated aging of the world population. The traditional view contextualizes aging linked to central countries. Europe, in particular, is linked to this context. However, on this continent live about $12 \%$ of the world population and $28 \%$ of people over the age of 75. On the other hand, there was a real demographic explosion of the elderly in developing countries at the end of the 20th century. In Latin America, the elderly population has grown by $236 \%$ in the last two decades. These transformations imply a change in the attitude of all social segments, including those related to health (Maresova et al., 2015; Banerjee, 2012).

Alzheimer's dementia has a higher prevalence in middle age, accounting for 60 to $80 \%$ of all dementia cases in the world. In the United States the disease affects more than 5.4 million Americans and may be the fourth leading cause of death (Sadock \& Sadock, 2009). The risk of developing AD increases, among other factors, with advancing age, it is estimated that in developed countries, the prevalence of the disease is approximately $1.5 \%$ around 65 years until reaching $30 \%$, on average, 
around 80 years (Ritchie \& Lovestone). Still in the United States, from 3\% to $11 \%$ of people over 65 , have some type of dementia, this rate increases even more when we delimit to individuals over 85 years, where the prevalence reaches up to $47 \%$.There is a projection that there will be 16 million Americans with Alzheimer's disease by the year 2050, unless methods capable of minimizing or neutralizing such progressions are developed (Liesi et al., 2013; Aprahamian et al., 2009).

The etiopathogenesis of Alzheimer's disease has not yet been fully clarified, there are currently several pathophysiological and etiopathogenic hypotheses. In recent decades there have been great advances in understanding the origin of the main form of presentation. The deposition of amyloid and neurofibrillary tangles in the cytoplasm of neurons is one of the main hypotheses, however it is not yet possible to affirm with certainty the origin of the physiopathogenic mechanism of the disease. This disease is characterized histopathologically by massive symptic loss and neuronal death observed in the brain regions responsible for cognitive functions, including the cerebral cortex, hippocampus, entorrine cortex and ventral striatum. Regarding the pathophysiological aspects of $\mathrm{AD}$, these are related to neuropathological activities that affect neurotransmitters. A striking feature of the brain affected by $\mathrm{AD}$ is the presence of senile plaques composed of pathogenic extracellular deposits of $\beta$-amyloid (A $\beta$ ), a peptide composed of up to 42 amino acids derived from the pathological processing of the precursor protein of transmembrane amyloid. Such fragments play a major role in the genesis of the disease, generating neuronal cell death. The senile plaques formed in this process are located in several regions of the brain, but the cerebral cortex, amygdala and hippocampus are particularly vulnerable, and plaques begin to form in these regions at the beginning of the disease process, resulting in memory loss and possible behavioral changes (Stuart, 2017; Attems et al., 2017).

This disease is characterized by progressive cortical atrophy, which generates irreversible damage to neurons, particularly in the parietal and temporal lobes. The main microscopic characteristics of AD are the formation of neurofibrillary tangles, neuritic plaques and amyloid angiopathy ${ }^{[21]}$. Currently there is evidence that $\mathrm{A} \beta$ is the critical molecule in the pathogenesis of AD. The normal degradation of the amyloid precursor protein (PPA) involves the middle cleavage of the A $\beta$ domain by a proteolytic enzyme, $\alpha$-secretase, with the release of two non-amyloid soluble pieces. However, PPA can also be cleaved at each end of the $A \beta$ domain, which generates the release of intact and highly amyloidogenic $A \beta$ that accumulates in senile plaques such as amyloid fibrils (Gallardo \& Holtzman'2019; Weller \& Budson, 2018).

In terms of neurochemistry, $\mathrm{AD}$ is associated with a decrease in the level of choline-acetyltransferase activity in the cortex and hippocampus. This enzyme is necessary for synthesis of acetylcholine, a memory-related neurotransmitter. The reduction of this substance is quantitatively related to the number of neuritic plaques and the severity of dementia (FerreiraVieira et al., 2016).

\section{Natural cannabinoids: from discovery to the current level}

One of the major challenges of Pharmaceutical Chemistry is the obtaining of new chemical structures that will serve as a basis for new therapeutic agents. For a long time, the plants were almost exclusive in the therapy available to man. Over the centuries, the therapeutic use of the various chemical properties provided by vegetables has become increasingly common, being essential for the pharmaceutical industry today (Cavalcante \& Fernandes, 2019).

In this evolution Cannabis sativa and its derivatives have acquired an exponential importance, however, the study of its properties, its analogues and cannabinoid receptors and the enzymes involved in its metabolism is very recent. Such a plant was one of the first to be cultivated by man. Known as hemp plant, Cannabis sativa, originating from tropical and temperate regions, was used by ancient civilization as a source of fibers for the manufacture of fabrics and cordoaria produced from its stem, given their high strength. Present-day China was the locality where the first remnants of this fiber were discovered, dating from approximately 4000 years BC. Such material would have been used for medicinal and spiritual purposes. The use 
of cannabis components in Eastern Chinese medicine is reported in the world's oldest pharmacopoeia known as Pen-ts' Chin where the use of cannabis in the treatment of various comorbidities is described, such as intestinal problems, rheumatic pain, malaria and problems in the female reproductive system (Greydanus \& Holt, 2014; Kalant, 2001).

In ancient India cannabis was used by Hindus with spiritual functions, and for meditation, in addition to medical uses in the treatment of insomnia, fevers, dry cough, ophthalmology and dysentery. The introduction of cannabis in Europe takes place in the 17th century, after General Bonaparte's invasion of Egypt. In this invasion Bonaparte was accompanied by two French doctors, De Sacy and Rouyer, who collected samples of the plant for further study in Europe (Greydanus \& Holt, 2014; Kalant, 2001).

After the discovery of endogenous cannabinoids, scientific studies focused on the investigation of their clinical potential. Scientific evidence has shown that there is dysfunction in the endocannabinoid system, target of phytocannabinoids cannabidiol (CBD) found in cannabis sativa, in pathological conditions of the central nervous system. The investigation of the therapeutic potential of CBD in neurological and psychiatric diseases began in the 1970s and, since then, it has been evaluated as a possible alternative or adjuvant in the treatment of these neuropsychiatric conditions, since most drugs introduced in recent decades only reduced the side effects of pharmacological treatments already available, that is, there has not been a significant improvement in the efficacy of treatment (Devane et al., 1992)

More recently, an increasing number of evidences has suggested antioxidant, anti-inflammatory and neuroprotective activities of the cannabinoid system. Such properties can be used to soften the neurodegenerative process by offering more effective approaches to the treatment of $\mathrm{AD}$. The last two decades of research have brought a significant better knowledge related to the components and functions of the endocannabinoid system in physiological and pathological conditions. Such a neuromodulatory system consists of cannabinoid receptors, endogenous ligandsand various enzymes responsible for its synthesis and degradation (Greydanus \& Holt, 2014; Devane et al., 1992).

\section{Mechanisms of action of natural cannabinoids in the retardation of Alzheimer's disease}

Natural cannabinoids originate from the cannabis sativaplant, which has as main active substancescannabinol (CBD), delta-9-tetrahydrocannabinol ( $\Delta^{9}$-THC) and tetrahydrocannabivarin. The discovery of an endogenous cannabinoid (CB) signaling system in the brain has led to many researches the search for a better understanding of this biological phenomenon, which regulates physiological and pathological events in the central nervous system. The activation of the biochemical mechanisms of cannabinoids are mainly based on the activation of the endocannabinoid system, through specific receptors, which provide the release of neurotransmitters, especially glutamate (Honório et al., 2006).

The human body has two types of specific receptors sensitive to cannabinoids, CB1, predominant in the central nervous system, and CB2, which constitutes the main receptor of peripheral tissues. Endocannabinoids constitute a class of neural messengers which are synthesized in a controlled manner, and together with post-synaptic neurons, aim to restrict the release of classical neurotransmitters from presynaptic terminals. This retrograde signaling modulates a diversity of brain functions, including anxiety, fear, and mood, thus allowing the activation of CB1 receptors to exert anxiolytic and antidepressant effects, already observed in preclinical studies (Burnstock, 2009; Ross 2007).

These criteria make the messenger endocannabinoids atypical, which support the transfer of information between the post-to-pre-synaptic terminals retrogradely. Endocannabinoids are synthesized on demand and are not stored in vesicles. The synthesis occurs in post-synaptic neurons after calcium influx and subsequent activation of phospholipases (phospholipase $\mathrm{D}$ in the case of anandamide and diacylglycerol lipase in the case of 2-AG), which convert phospholipids into endocannabinoids (Piomelli, 2003). They seem to interact immediately with the synaptic cleft through free or assisted diffusion by attaching to 
presynaptic CB1 receptors. Through a complex network of intracellular signaling processes, the activation of CB1 receptors finally results in a decrease in calcium influx in axon terminals and, thus, in the decrease of transmitter release. In addition to the activation of CB1, activation of TRPV1 receptors by anandamide leads to increased depolarization of post-synaptic membranes. However, the activation of CB1 and TRPV1 seems to exert opposite effects (Glaser et al., 2003; Dinh 2002 et al., 2002).

Equally as they occur with classical neurotransmitters, the actions performed by the endocannabinoids are developed by a process with two stages: internalization, followed by catabolism. The first stage is not yet fully understood, currently there are debates in the scientific community about how the internalization of endocannabinoids occurs passively through diffusion or by specific transporters. In the post-internalization phase, endocannabinoids undergo enzymatic hydrolysis. Such enzymes are responsible for hydrolysis of anandamide and 2-AG. It is noteworthy that the two endocannabinoids are degraded both in the presynaptic (2-AG) and post-synaptic (anandamide) form (Glaser et al., 2003; Dinh 2002 et al., 2002).

In the last decade, the propensity of cannabinoids to exert a neuroprotective influence has provoked a great interest in the scientific community, which seeks to better understand how to mitigate the symptoms of neurodegenerative conditions. In the brains of Alzheimer's patients, changes in the components of the cannabinoid system were observed, suggesting that such a system contributes or is altered by the pathophysiology of the disease. It is known that certain cannabinoids can protect neurons from the deleterious effects of $\beta$-amyloid, thus reducing the phosphorylation of protein tau. There is also a propensity of cannabinoids to reduce oxidative stress and neurodegeneration evoked by $\beta$-amyloid, stimulating the neurogenesis of neurotrophin expression, such properties can be extremely beneficial in the treatment of Alzheimer's disease (Freeman et al., 2019).

Delta-9-tetrahydrocannabinol $(\triangle 9-\mathrm{THC})$ has the ability to inhibit acetylcholinesterase thus limiting amyloidogenesis, which can in thesis, improve cholinergic transmission and slow the progression of the disease. The targeting of cannabinoid receptors to microglia can reduce neuroinflammation that is a characteristic of Alzheimer's disease, without causing psychoactive effects ${ }^{35}$.Thus, cannabinoids offer a multifaceted approach to the treatment of the disease, providing neuroprotection and reducing the possibility of neuroinflammation, simultaneously supporting the intrinsic repair mechanisms of the brain, significantly increasing neurotrophin expression and improving neurogenesis. Another interesting mechanism that could explain the ability of cannabinoids to confer neuroprotection may be related to their regulation of neurogenesis. Adult neurogenesis may occur in the toothed gyre of the hippocampus and in the subventricular zone (Grote \& Hannan, 2007). Thus, resulting in the presence of newly generated neurons. Other factors that improve neurogenesis, such as adequate feeding and positive regulation of brain-derived neurotrophic factor, improve neurogenesis and improve memory performance in research using animals affected by AD. Thus, the direction of adult neurogenesis is being considered as a means of mitigating the symptoms of such pathology (Krebs et al., 2020; Gomazkov, 2013).

Activation of the $\mathrm{CB}_{2}$ receptor also stimulates the proliferation of neural progenitors invitroand in vivo and targets neurogenesis via CB2 the receptor would avoid unwanted psychoactive side effects. Thus, the neuroprotective effects of cannabinoids may involve short-term adaptation to neuronal stress, such as excitotoxicity limitation, as well as long-term adaptations such as increased neurogenesis. It remains to be established whether the beneficial effects of cannabinoids on memory, neuroinflammation and neurodegeneration in research with animals possessing AD are due to a functional consequence of an improvement in neurogenesis (Krebs et al., 2020; Gomazkov, 2013). 


\section{Natural and perspective cannabinoids for the future}

Currently, it is known that cannabinoids have great potential to, in the future, be an important therapeutic option in the treatment of AD. This fact is mainly due to the absence of psychoactive effects on cognition, safety, good tolerability, clinical trials with positive results and the broad spectrum of pharmacological actions. In these questions, CBD seems to be the cannabinoid alone closest to having its initial findings used in clinical practice. In particular, the results of CBD as a drug capable of delaying the pathophysiological effects of $\mathrm{AD}$ seem to be well established. However, double-blind, placebocontrolled studies in samples with a high number of patients in the different pathological stages of the disease are still necessary and timely (Crippa et al., 2018; Aso \& Ferrer, 2014). It is noteworthy that due to the actions of CBD being biphasic, the determination of the appropriate therapeutic range for each phase of the pathology is still a challenge. At the same time, more research aiming to determine more specifically the main mechanisms of CBD action in different neuropsychiatric conditions are still desirable (Amandine \& Yannick, 2015).

In relation to $\triangle 9$-THC and its analogues, it is known that much of its effects are mainly caused by its binding to $\mathrm{CB}_{1}$ cannabinoid receptors, present in many areas of the brain. Such receptors have importance in various physiological processes of the human body, among them, regulation of metabolism, pain, bone growth, anxiety and even in immunity. However, despite the various benefits, it has long been reported that these compounds have some acute toxicological effects. Acute toxicity of THC is incredibly low. The lethal dose in humans is not yet well established, and there are no proven reports of deaths in humans caused by THC or Cannabis (Amandine \& Yannick, 2015). The duration, severity and frequency of these symptoms vary according to the susceptibility of the individual and the frequency and intensity of previous cannabis use. Despite these aspects, pure delta-9-tetrahydrocannabinol ( $\triangle 9-\mathrm{THC})$ and its analogues have good clinical applicability, demonstrating varied benefits. The improvement and development of pure synthetic substances, in the search for the attenuation of undesirable psychoactive effects, point to promising prospects for their use in the future. However, more detailed studies should be carried out, as well as broad discussions will be necessary to create standards of formulation and availability for medical purposes, mainly because it is a substance that generates prejudice by its commercialization and illegal use (Huestis et al., 2019; Mannucci et al., 2017).

The development of new synthetic analogues of THC, with a better separation between therapeutic and side effects may be a promising alternative for the new therapy of AD. Scientific perspectives point to THC and its analogues as a possible treatment option, improving quality of life and providing more dignified end of life for some patients (Boggs et al., 2018). Cannabis and its derivatives throughout its history have always aroused and have also aroused many discussions. Currently, as it is considered an illicit drug in several countries, world data do not rule out the fear of research in the area that ends up stimulating the illegal use of it. The tension generated between those who advocate its prohibition/legalization, or consumption for medicinal purposes has not come to an end. Certainly, in a few years, and with the development of new studies we will know the answer to this duality. Therefore, there is still much to be researched about this drug and its pharmacokinetic and pharmacodynamic mechanisms of action, in order to minimize as much as possible side effects in the search for a more efficient therapeutic response (Libro et al., 2016 ; Cheng et al., 2014).

Several studies have corroborated about the therapeutic benefits provided by CBD, and its analogues. In the last decade, the literature has been converging more and more in this direction, with increasingly concrete evidence, and the number of information on the topic grows exponentially each year (Libro et al., 2016). 


\section{Conclusion}

Alzheimer's disease is a devastating pathology for which so far there is no cure. Current AD medications, which serve as AChE (accetylcholinesterase) inhibitors, have several unpleasant side effects such as gastrointestinal disorders and have a certain degree of hepatotoxicity. Although the NMDA receptor antagonist, memantine, can modify the disease, it is not able to reverse the neurodegenerative process. Efficient manipulation of the cannabinoid pathway offers a new pharmacological approach for the treatment of $\mathrm{AD}$, with the potential to become more effective than current treatment methods. Cannabinoids can reduce oxidative stress, neuroinflammation and apoptosis caused by beta amyloid substances (A $\beta$ ), while promoting the intrinsic mechanisms of celebratory repair. Certain cannabinoids, such as $\triangle 9$-THC, may also increase the availability of ACh reducing amyloidogenesis, although potential psychoactive side effects may impair its clinical usefulness. Cannabinoids currently offer a multifaceted approach to the treatment and pathophysiological retardation of AD, future studies should focus on analyzing the efficacy of cannabinoids in several animal models exhibiting pathology with characteristics similar to AD, which cause cognitive decline. The targeting of the $\mathrm{CB}_{2}$ receptor used as a reductive of neuroinflammation, stimulating neurogenesis, will probably be of particular interest given the reduced risk of psychoactive activity, thus limiting the drug effects, thus sparing the possible generalized effects that could be caused in normal neurophysiological processes. In conclusion, manipulation of the cannabinoid system offers the potential to positively regulate neuroprotective mechanisms while attenuating neuroinflammation. Whether these properties will be beneficial in the treatment of AD in the future is an interesting topic that undoubtedly deserves further research.

\section{Acknowledgments}

This research received no specific grant from any funding agency in the public, commercial, or not-for-profit-sectors.

\section{References}

Agüera, O. L., \& López, A. J. (2017). Mild behavioral impairment: a new concept for the prodromic phases of dementia. Rev Esp Geriatr Geronto; 52 (Suppl. 1): 24-27. 10.1016/S0211-139X(18)30076-3.

Amandine, E. B., \& Yannick, M. (2015). Potential Therapeutical Contributions of the Endocannabinoid System towards Aging and Alzheimer's Disease. Aging Dis; 6(5): 400-405. 10.14336 / AD.2015.0617.

Aprahamian, I., et al. (2009). Alzheimer's Disease: An Epidemiology and Diagnosis Review. Rev Bras Clin Med; 7(1): 27-35.

Aso, E. \&, Ferrer, I. Cannabinoids for treatment of Alzheimer's disease: moving toward the clinic. Front Pharmacol. 2014; 37(5): 1-11. 10.3389/fphar.2014.00037.

Attems, J.. et al. (2017). Alzheimer's disease pathology in synucleinopathies. Lancet Neurol; 16(1): 22-23. https://doi.org/10.1016/S1474-4422(16)30282-4.

Banerjee, S. (2012). The Macroeconomics of dementia-will the world economy get Alzhimer's disease? Arch Med Res; 43(8): 705-709. 10.1016/j.arcmed.2012.10.006.

Blesa, R., et al. (2018). Strategies for Continued Successful Treatment in Patients with Alzheimer's Disease: An Overview of Switching Between Pharmacological Agents. Curr Alzheimer Res; 15(10): 964-974. 10.2174/1567205015666180613112040.

Boggs, D. L., et al. (2018). Ranganathan M. Clinical and Preclinical Evidence for Functional Interactions of Cannabidiol and $\Delta^{9}$ Tetrahydrocannabinol. Neuropsychopharmacology. 2018;43(1):142-154. 10.1038/npp.2017.209. 10.1038/npp.2017.209.

Bondi, M. W., et al. (2017) Alzheimer's Disease: Past, Present, and Future. J Int Neuropsychol Soc; 23 (9-10): 818-831. https://doi.org/10.1017/S135561771700100X.

Burnstock, G. (2009). Autonomic neurotransmission: 60 years since sir Henry Dale. Annu Rev Pharmacol Toxicol; 49(1):130. 10.1146/annurev.pharmtox.052808.102215.

Cavalcante, D. A. L., \& Fernandes, L. T. (2019). The rational use of phytotherapy: demystifying common sense. Braz J Pharm; 100(1): $3295-3313$ [in Portuguese].

Cheng, D., Low, J. K., Logge, W., Garner, B., \& Karl, T. (2014). Chronic cannabidiol treatment improves social and object recognition in double transgenic APPswe/PS1 1 E9 mice. Psychopharmacology.; 231(15):3009-3017. 10.1007/s00213-014-3478-5. 
Crippa, J. A.. et al. (2018). Translational Investigation of the Therapeutic Potential of Cannabidiol (CBD): Toward a New Age. Front. Immunol.; 9(1): 1-16. 10.3233 / JAD-160882.

De Falco, A., et al. (2016). Alzheimer's disease: Etiological hypotheses and treatment perspectives. Quím. Nova; 39(1): 63-80. https://doi.org/10.5935/01004042.20150152.

Devane, W. A., et al. (1992). Isolation and structure of a brain constituent that binds to the cannabinoid receptor. Science 1992; $258(5090)$ : 1946-1949. 10.1126/science.1470919.

Dinh, T. P., et al. (2002). Brain monoglyceride lipase participating in endocannabinoid inactivation. Proc Natl Acad Sci; 99(16): 10819-10824. $10.1073 /$ pnas. 152334899 .

Dong, H., et al. (2016). Label-Free Electrochemical Biosensor for Monitoring of Chloride Ion in an Animal Model of Alzhemier's Disease. ACS Chem Neurosci; 8(2): 339-346. https://doi.org/10.1021/acschemneuro.6b00296.

Fan L. et al. (2020). New Insights Into the Pathogenesis of Alzheimer's Disease. Front Neurol; 10 (article 1312): 1-12.

Ferreira-Vieira, T. H., et al. (2016). Alzheimer's Disease: Targeting the Cholinergic System. Curr Neuropharmacol.; 14 (1): 101-115. $10.2174 / 1570159 \times 13666150716165726$.

Freeman, A. M., et al. (2019). How does cannabidiol (CBD) influence the acute effects of delta-9-tetrahydrocannabinol (THC) in humans? A systematic review. Neurosci Biobehav Rev.; 107(1): 696-712. 10.1016/j.neubiorev.2019.09.036.

Gallardo, G., \& Holtzman, D. M. (2019). Amyloid- $\beta$ and Tau at the Crossroads of Alzheimer's Disease.Adv Exp Med Biol; $1184(1): 187-203$. 10.1007/978981-32-9358-8_16.

Glaser, S. T.. et al. (2003). Evidence against the presence of an anandamide transporter. ProcNatl Acad Sci; 100(7): 4269-4274. 10.1073/pnas.0730816100.

Gomazkov, O. A. (2013). Signaling molecule as regulators of neurogenesis in the adult brain. Neurochem J.; 7(1): 241-255. https://doi.org/10.1134/S1819712413040041.

Greydanus, D., \& Holt, M. (2014). Cannabis: a controversial drug from 21 st century antiquity. Georgian Med News; 230(1): 24-30.

Grote, H. E., \& Hannan, A. J. (2007). Regulators of adult neurogenesis in the healthy and diseased brain. Clin Exp Pharm Phys.; 34(1): 533-545. 10.1111/j.1440-1681.2007.04610.x.

Honório, K. M., et al. Aspectos terapêuticos de compostos da planta Cannabis sativa.Quím. Nova; 29(2): 318-325. https://doi.org/10.1590/S010040422006000200024.

Hane, F. T., et al. (2017). Recent Progress in Alzheimer's Disease Research, Part 3: Diagnosis and Treatment. J Alzheimers Dis; 57(3): 645-665. 10.3233 / JAD-160882.

Huestis, M. A., Solimini, R., Pichini, S., Pacifici, R., Carlier, J, \& Busardò, F. P. Cannabidiol Adverse Effects and Toxicity. Curr Neuropharmacol.; 17(10): 974-989. 10.2174/1570159X17666190603171901.

Kalant, H. (2001). Medicinal use of cannabis: history and currentstatus. Pain Res Manag; 6 (2): 80-91. 10.1155/2001/469629.

Kantarci, K., et al. (2020). $\beta$-Amyloid PET and neuropathology in dementia with Lewy bodies. Neurology; 94(3): e282-e291.

Krebs, M. O., et al. (2020) Cannabis et neurodéveloppement. Bull Acad Natl Med. 2020; 204(6): 561-569. 10.1016/j.banm.2020.04.002.

Liesi, E. H., et al. (2013). Alzheimer disease in the United States (2010-2050) estimated using the 2010 census. Neurology; 80 (19): 1778-1783. 10.1212/WNL.0b013e31828726f5.

Libro, R., Diomede, F., Scionti, D., et al., Cannabidiol Modulates the Expressionof Alzheimer's Disease-Related Genes in Mesenchymal Stem Cells. Int J Mol Sci. 2017; 18(1):26. 10.3390/ijms18010026.

Mannucci, C., et al. (2017). Neurological Aspects of Medical Use of Cannabidiol. CNS Neurol Disord Drug Targets .; 16 (5): $541-553$.

Maresova, P., et al. (2015). Socio-economic Aspects of Alzheimer's Disease. Curr Alzheimer Res; 12(9): 903-911. 10.2174/156720501209151019111448.

McDonough, I. M. (2017). Beta-amyloid and Cortical Thickness Reveal Racial Disparities in Preclinical Alzheimer's Disease. Neuroimage Clin 2017; 16(2017): 659-667.

Oliveira, B. C. L., et al. (2018). Inflammation as a Possible Link Between Dyslipidemia and Alzheimer's Disease. Neuroscience; 376(1):127-141. 10.1016/j.neuroscience.2018.02.012.

Piomelli, D. (2003). The molecular logic of endocannabinoid signalling. Nat Rev Neurosci.; 4(11): 873-84. DOI: $10.1038 / \mathrm{nrn} 1247$.

Ross, R. A. (2007). Allosterism and cannabinoid CB(1) receptors: the shape of things to come. Trends Pharmacol Sci; 28(11): 567-72. 10.1016/j.tips.2007.10.006.

Ritchie, K., \& Lovestone S. The dementias. (2002). Lancet; 360(1): 1759-1766. 10.1016/S0140-6736(02)11667-9. 
Research, Society and Development, v. 10, n. 6, e0310615418, 2021

(CC BY 4.0) | ISSN 2525-3409 | DOI: http://dx.doi.org/10.33448/rsd-v10i6.15418

Robinson, M., et al. (2017). Recent Progress in Alzheimer's Disease Research, Part 2: Genetics and Epidemiology. J Alzheimers Dis $2017 ; 57$ (2017) $317-330$. 10.3233/JAD-161149

Sadock, B. J., \& Sadock, V. A. (2009) eds. Kaplan \& Sadock's comprehensive text book of psychiatry, (9 ${ }^{\text {th }}$ ed.): Lippincott Williams \& wilkins.

Stuart, P. A. (2017). Alzheimer's disease: a special collection. Stem Cells Transl Med; 6 (11): 1951-1955. 10.1002/sctm.12217.

Watt, G., \& Karl T. (2017). In vivo Evidence for Therapeutic Properties of Cannabidiol (CBD) for Alzheimer's Disease. Front Pharmacol; 8(20):1- 7. $10.3389 /$ fphar.2017.00020.

Weller, J., \& Budson, A. (2018). Current understanding of Alzheimer's disease diagnosis and treatment.Neuropharmacol; 2018(7): 1-9. 10.12688/f1000research.14506.1.

Xie, Z., et al. (2020). Magnolol alleviates Alzheimer's disease-like pathology in transgenic C. elegans by promoting microglia phagocytosis and the degradation of beta-amyloid through activation of PPAR- $\gamma$. Pharmacother Biomed 2020; 124(2020): 1-12. 